\title{
Making Military Histories in Museums Editorial Introduction
}

\author{
Sheila Watson*, Alastair Massie**
}

The papers in this section of the November edition of Museum and Society are the result of a conference held jointly by the National Army Museum and the School of Museum Studies, Leicester, in September 2013. The call for papers asked academics and professional museum curators, along with interested members of the public and former army personnel, to think about the challenges the Museum faced as it planned a £23 million Heritage Lottery Fund redevelopment project.

The conference engendered lively debates and opened up discussions on a range of practical and intellectual issues around the collection, research, care and exhibition of military objects. Unlike many academic conferences (held usually in universities) this event, hosted by the National Army Museum in London, did indeed attract many interested members of the public, some former army personnel, whose contribution added new insights to the debates. In addition we were fortunate to attract professional curators, designers and educators all working in this field.

Inevitably many of the contributors to the conference did not have the time to write up their papers for an academic journal. Nevertheless our call for papers arising from the conference for this journal attracted a pleasing number of submissions many of which are included here.

Among the enlightening and thought provoking papers that, for various good reasons, did not make it into this Journal were two papers that looked back to the early years of the Imperial War Museum (IWM). These provided an instructive contrast to the update the audience received from another contributor on the redevelopment IWM London then had in hand.

Ensuring that expectations are met was the theme of a paper delivered on audience research for the First World War exhibition then being planned at the Science Museum, and the sheer hard work involved in mounting a European Union-funded travelling exhibition where there were a plethora of different stakeholders to satisfy vividly emerged in a presentation on the Liberation Route Europe Foundation's commemoration plans for 2014.

Three papers by given members of the School of Museum Studies, Dr Viv Golding on 'Narrative and Affect in Kurdistan Museums' and Dr Ceri Jones and Jocelyn Dodd presenting on 'The Impact of War and Conflict: Using Museum Collections, Personal Experiences and Intergenerational Practice to Develop People's Understanding' and DrAmy Barnes 'Representing the Soviet "Other" in British Cold War Museums' debated some of the challenging issues arising from these topics.

In the end, central to the conference was the dialogue between museum professionals and university researchers, and this was triumphantly given flesh in a joint paper delivered by Alan Popper (Royal Lincolnshire Regiment Museum) and Claire Hubbard-Hall (Bishop Grosseteste University) which demonstrated that object-based learning in higher education could be facilitated to advantage by military museums.

Turning now to the papers we are pleased to include here, it can be seen that they cover diverse approaches and incorporate a variety of disciplines. Military history can all too often be seen as something to be put in a silo, labelled military, which can thus be contained and managed, so only those who are interested in it need engage with the complex moral, emotional and ethical issues that the subject raises. However, nearly all museums have materials possessing military connotations, such as the V\&A's quilts sewn by soldiers, and Furneaux and Pritchard's paper investigating these quilts encourages consideration of the complex emotional engagement a work made of pieces of uniform from often now dead colleagues engenders. The two speakers' paper considers the personal, the private and the gendered world of the soldier outside the framework of the battlefield, reminding us that close 
engagement with the enemy has consequences for individual soldiers long after wars are over. For some, this type of sewing enabled them to remember former comrades and to celebrate their lives in a private manner.

Indeed the conference focussed as much on the individual experience as it did on the military consequences of war and we reproduce here. Haymond's contribution The Muted Voice, a moving and thoughtful consideration of the soldier's war and how far some museums are from exhibiting this reality. We reproduce it here because it reminds those of us who engage with these intellectual interests that the experiences of soldiers can be forgotten in the exhibitions of hardware, accounts of military strategy and the celebration of medals and victories won. Whatever our views of wars now and in the past this piece reminds us that they were all fought by people who made enormous personal sacrifices for their nation. At the same time, Tythacott's paper on the looting of the Summer Palace by the British in the nineteenth century demonstrates that some of the difficult, illegal and unpleasant aspects of war can be re-positioned in military museums whose purpose it is to celebrate or commemorate a nation or regiments. In this light, James Scott's paper considers the way war is depicted and its influence on the public.

Nations are often defined by their military defeats and successes. Bates's contribution looks at how an event, in her instance the Charge of the Light Brigade, becomes through various media such as poetry, film, images and museum displays, a symbol of British pride even though it was a tragic mistake with appalling consequences. Throughout the world museums present the nation through the lens of war and this kind of nation-making deserves more attention. One has only to go to a museum such as the Museum of Artillery, Engineers and Signals, St Petersburg or the National Military Museum Bucharest, the exhibition The Price of Freedom: Americans at in the National Museum of American History, Washington, or the Australian War Memorial Canberra to find out how a nation sees itself, the key events that have defined its character and the role it sees itself playing in the world.. Closer to home, for example, the National War Museum of Scotland goes out of its way to display a form of Scottish nationhood which endures even when soldiers fight under the British flag (both reflecting and, one can conclude, contributing to the current resurgence of Scottish nationalism).

Meanwhile, Angela Loxham in her paper on the Imperial War Museum North reminds us that we need to consider Military Museums holistically, looking at aspects such as architecture and shops, and considering the whole military experience. This is something all curators and designers wrestle with in practice.

In the end the conference succeeded in its aims of supporting the National Army Museum staff as they embarked on the challenge of transforming the Museum and making it fit for the twenty-first century. The Museum's staff, who had been grappling with some of the problems associated with switching from a chronological to a thematic approach in their new galleries, found the issues raised by the conference's papers thought-provoking throughout. How might one best explain the provenance of objects looted from the Summer Palace in Beijing in 1860 ? How could the reality of combat be represented in a museum's displays? How could the desire of many military museums to commemorate be reconciled with the requirement of some visitors for a more critical appraisal?

Thus these papers represent a small selection of some of those topics that engage academics and professionals together when they are working in the intersections between practice and theory. The new National Army Museum plans to open at the end of 2016 and we hope to see you there.

*Dr Sheila Watson, Senior Lecturer, Programme Director Heritage and Interpretation, Director of Flexible Learning.School of Museum Studies, Leicester, LE1 7RF.

serw1@le.ac.uk

**Dr Alastair Massie, Head of Academic Access, National Army Museum . amassie@nam.ac.uk 